\title{
XLII. On the spiral vibration of a stick or rod
}

\section{G.F.F. Chladni}

To cite this article: G.F.F. Chladni (1802) XLII. On the spiral vibration of a stick or rod, Philosophical Magazine Series 1, 12:47, 259-260, DOI: 10.1080/14786440208676057

To link to this article: http://dx.doi.org/10.1080/14786440208676057

$$
\text { 册 Published online: } 18 \text { May } 2009 .
$$

Submit your article to this journal

LII Article views: 2

Q View related articles $\asymp$ 
XLII. On the Spiral Vibration of a Stick or Rod. By G. F. F. CHLADNI *

$\mathrm{T}$ $\mathrm{HE}$ vibrations hitherto known of a ftick or rod, that is to fay, of an elaftic boly extended in a certain direction, are either tranfverfal vibrations, where the rod or the parts into which it divides itfelf vibrate fidewards, in fuch a manner as to form a great number of curved lines; or longitudinal vibrations, where the rod or each of its parts contracts and extends itfelf according to the direction of its length, fo that it fometimes refts againft one and fometimes againft the other of the vibration nodes. The former kind of vibrations were firt determined by Daniel Bernoulli, and afterwards, in a more complete manner, by Euler, in the Tranfactions of the Imperial Academy of Sciences for 1769: but the latter were firt made known by myfelf in a paper on the longitudinal vibrations of rods and ftrings, publithed at Erfurt in 1796 , and which may be found alfo in the Tranfactions of the Electoral Academy of Sciences of that city. For fome time I have obferved, that, befides thefe two directions of vibrating motion, there is a third, where the rod, or each part into which it divides itfelf, turns alternately to the right and left in a fpiral form, while the vibration nodes or the boundariss of the vibrating parts remain motionlefs, as in the other kinds of vibration. Such fpiral vibrations may be produced with moft eafe on a fufficiently long cylindric rod, the furface of which has been made as fmooth as poffible, if the rod be held gently between two fingers at the place where there is a vibration node, and if it be rubbed in a fpiral direction in a vibrating part with a piece of woollen rag held between the fingers of the other hand. When the rod is of wood or metal, the rag muft be previouly ftrewed over with refin; but when a glafs rod, or, what is the fame thing, a thermometer or barometer tube is employed, it muft be moiftened with water, or be ftrewed over with very fine fand. The ways in which a rod, when it is either entirely free, or faftened at one end and free at the other, or faftened at-both ends, can divide itfelf into vibrating parts, and the pofition of the vibration nodes, are entirely the fame as in the cafe of longitudinal vibrations. The tharpnefs and flatnefs of the tone depend alfo on the fame laws; and therefore, to avoid all unneceffary prolixity, I hall refer to the above-mentioned effay

* From Der Gefellfcbaft Natu forfcbender Freunde zu Berlin Neue Scbriften, vol. ii. 7999 . 
on longitudinal vibrations. There is this difference, bowever, that, as far as I have obferved, the tone, when the vibrations take place in a fpiral direction, is a fifth lower than when the rod vibrates in a longitudinal direction under the fame circumftances.

By the fpiral vibration one phænomenon, which I bave mentioned in my difcoveries refpecting the theory of found, but refpecting which I formed an erroneous opinion, can be explained. On a prifmatic rod, one end of which was faftened in a vice, when $I$ rubbed one of its edges, in a diagonal direction, with' a violin bow, and ftrewed fand over one of its horizontal fides, there appeared on this fide a line proceeding along its length, where the fand, which was thrown from the other parts by the vibration; remained at reft ; and this appearance took place on each fide of the rod when held horizontally. The reafon of this is, becaufe at the edges which are further diftant from the axis the range during the vibrations is greater than in the middle of each fide; and on this account the fand which is thrown from the nearer places to thofe on the edges muft accumulate themfelves longitudinally in the middle of each fide neareft the axis where the vibrations are weakeft.

XLIII. Obfervations on Maddering; togetber with a fimple and certain Procefs for obtaining, witb great Beauty and. Fixity, that Colour known under tbe Name of tbe Turkey or Adrianople Red. By J. M. Ha us s m a N.

[Concluded from p. 175\%]

AFTER making a cauftic ley of one part of good common
potafh diffolved in four parts of boiling water, and half a part
of quicklime, which I afterwards flaked in it, I diffolved one
part of powdered alum in two parts of boiling water; and while
this folution of fulphate of alumine was ftill warm, to avoid
re-cryftallization, I peedily poured into it fucceffively, always
ftrring it withont interruption, the above-mentioned cauftic
ley, till the alumine it had at firt precipitated after faturation
to excefs with fulphuric acid had been rediffolved. I left at
reft this folution of alumine, which exhaled ammonia, and
which, on cooling, formed a precipitate of fulphate of potafh
in very fmalt cryttals. I then mixed a thirty-third part of
linfed- 